\title{
Use of Capital Investment Appraisal Practices and Effectiveness of Investment Decisions: A Study on Listed Manufacturing Companies in Sri Lanka
}

\author{
Kengatharan, L. (Corresponding author) \\ Department of Financial Management, University of Jaffna, Sri Lanka \\ E-mail: lingesiya@yahoo.com \\ C. Prashanth Diluxshan \\ Department of Financial Management, University of Jaffna, Sri Lanka
}

Received: Nov. 3, 2017 Accepted: Dec. 15, $2017 \quad$ Published: December 15, 2017

doi:10.5296/ajfa.v9i2.12229 URL: https://doi.org/10.5296/ajfa.v9i2.12229

\begin{abstract}
Primary objective of the present study was to examine the relationship between use of capital investment appraisal practices and effectiveness of investment decision of listed manufacturing companies in Sri Lanka. Capital investment appraisal practices were measured by capital investment appraisal techniques and risk analysis techniques of investment projects. Effectiveness of investment was measured by perceptions of CFOs on the performance from investment. Firm size was used as the control variable to examine the relationship between investment appraisal practices and effectiveness of investment decision. The study employed a field survey from January to March 2017 and primary data was collected through self-administered questionnaires from randomly selected 20 listed manufacturing companies. Results of the study revealed that use of NPV and IRR have significantly positively related to effectiveness of investment decision while DPB has significantly negatively related to effectiveness of investment decision of listed manufacturing companies in Sri Lanka. Risk analysis techniques were not significantly related to effectiveness of investment decision. Findings of the study may useful to the investment decision makers in order to achieve the shareholders wealth.
\end{abstract}

Keywords: investment appraisal techniques, risk analysis techniques and effectiveness. 


\section{Background of the study}

Primary objective of financial management is to maximize the shareholders' wealth and principally concerns with three major decisions on investment (what to invest), financing (how to finance) and dividend decisions (how to reward shareholders) and interactions between them (Freeman \& Hobbes, 1991). Effective investment decision making is fundamental to corporate survival and long term success. In this scenario, investment appraisal practices are decisive to boost corporate performances as investment appraisal practices are process of evaluating and selecting long term investments consistent with the firm owners' goal of wealth maximization (Gitman, 1988). Recently more attention has been given to some of the theoretical issues apparent in organizational theory since they are parallel issues in the development of financial management research. Application of decision making of organizational theory to finance or investment decision predominantly important to improve the value of a company, support to organize organizational resource to achieve organizational goals and tells how to achieve expected results by the way of structuring activities and designing organizational processes (Hatch \& Cunliffe,2006). Managers and employees should focus to maximize both short term and long term investment yield. Nonetheless it is critical and challenging task making investment decision. Hatch and Cunliffe (2006) connotes that few would disagree about that organization works in complex, uncertain and often contradictory situations. However, in reality, making investment decision is heavily complex in a cut-throat competitive world. Decision making is not a simple task; its consequences are felt over many years in future (Bhimani, Horngren, Datar, \& Rajan, 2012). That is, any decision over investments of money would have uncertain actual results that could have effects on the organization for many years (Bhimani et al, 2012). Thus, effectiveness of investment decision is paramount important for organizational survival. For example, poor investment decision can affect the organizational stability and often difficult to recover the invested money in bad investment (Bhimani et al, 2012). This kind of the investment can have impact on firm's strategy, brand and culture in which organization operates. Thus the investment decision making may both directly and indirectly influence financial performance and economic viability. Therefore research problem of this study is how far use of investment appraisal practices influencing effectiveness of investment decision.

After the civil war the multinational companies were enter into the Sri Lankan market that means the most of Sri Lankan companies are involved with internationalization. Because of internationalization some companies needed to make long term investment decision so that companies involved with investment appraisal practices. So that making a good investment decision is of important since available funds are scarce and interdependency of organizational long-term survival, success and growth; in turn it boosts the value of the organization (Bennouna, Meredith \& Marchant2010). Thus, Elumilade, Asaolu and Ologunde, (2006) explained that capital investment decision is one of the fundamental requirements; it should be properly applied to make trade-offs between expected return and riskiness that route to the effective firm performance which accelerate the economic development of a country. Many 
changes involve capital investment decisions, which can invariably involve large sums of money over the long period.

'Capital investment decisions are critical in managing strategic change and sustaining long term corporate performance' (Emmanuel et al., 2010, p. 47 ). Instituting a systematic capital budgeting decision process proffers procedures to mitigate consequences of subjective capital expenditure decision making. The investment decision making is not a simple or straight forward approach, the risk is an important element in making investment decision. This study seeks to examine the relationship between investment appraisal techniques and effectiveness of investment decisions.

\section{Literature Review}

\subsection{Defining Capital Budgeting/ Investment Appraisal}

In the finance literature investment appraisal is known as capital budgeting. Ekeha (2011) explained that capital budgeting is an integral part of the corporate plan of an organization. Capital budgeting can be defined as 'the process of evaluating and selecting long term investment consistent with the firm owners' goal of wealth maximization' (Gitman, 1988). This is one of the important decision making process. It is a process of determining best investment projects which generate higher yielding in order to maximize shareholder value Dayananda, Irons, Harrison, Herbohn, and Rowland (2002). More simply, Quirin (1967) illustrated that capital budgeting is a stipulated avenue to invest present sum of funds more efficiently and effectively in the long run. However, Current financial theory requires that firm should maximize its market value of shares. Since capital investment decision deals with large sum of fund, it could cause drastic change in firms as well as in the whole economy. Therefore, capital investment decision is one of the most critical and crucial decision that needs to be taken carefully to achieve organizational growth as well as economic development.

\subsection{Investment Appraisal Techniques}

Seven investment appraisal techniques are more prevalent in today business world: net present value (Mao,1970; Elumilade et al. 2006; Ryan \& Ryan,2002; Pike,1988; Grahm \& Harvey,2001; Arnold \& Hatzopoulos,2000; Brounen, de Jong \& Koedijk,2004 ), profitability index (Mao,1970; Gitman \& Forrester,1977; Elumilade et al.2006; Ryan \& Ryan, 2002), internal rate of return (Mao,1970; Gitman \& Forrester,1977; Elumilade et al.2006; Ryan and Ryan,2002: Grahm \& Harvey,2001; Arnold \& Hatzopoulos,2000; Brounen, de Jong \& Koedijk,2004), modified internal rate of return (Ryan \& Ryan, 2002), payback (Pike,1996; Ryan \& Ryan,2002), discounted payback (Ryan and Ryan, 2002), and accounting rate of return (Pike,1996; Ryan \& Ryan,2002).

Net Present Value (NPV) of an investment is the aggregation of the present values of all cash benefits throughout the investment deducing the present value of all cash (Elumilade et al. 2006). Profitability Index (PI) is the ratio of the present value of future cash benefits at the required rate of return to the initial cash outlay, and thus referred to as "Benefits-Cost Ratio" (Elumilade et al. 2006). Internal Rate of Return (IRR) is the rate of interest at which the 
present value of expected capital investment outlays is exactly equivalent to the present value of expected cash earning on investment (Elumilade et al. 2006). Accounting Rate of Return (ARR) is the annual accounting profits from an investment, divided by annual average capital investment outlay over a project's life span (Elumilade et al. 2006). Payback Period (PB) describes how many years will be taken for the future net cash flows on a capital investment to pay back initial cash outlay (Elumilade et al. 2006).

\subsection{Discounted and non discounted cash flow methods}

Investment Appraisal can take either discounted cash flow (DCF) methods or non DCF methods. NPV and IRR are called DCF methods and PB and ARR are considered to be non DFC methods .Among these methods, from theoretical point of view, the NPV is widely used technique to evaluate investment projects however non DFC methods could be less accurate but least sophisticated (Brealey \& Myers, 2003).

However, Haka, Gorden and Pinches (1985) explained that the financial methods take two basic classes: sophisticated and naïve selection techniques. Discounted cash flow methods known as sophisticated techniques consider the risk adjusted discounted net cash flows expected from a project. It thus considers risk, cash flows and the time value of money. NPV, IRR and PI are the mainly employed sophisticated selection techniques. Non discounted cash flow methods known as naïve method does not use cash flow approach in contrast consider present value or incorporate risk in systematic way. ARR and PB are the mainly used naive selection techniques.

\subsection{Risk analysis techniques}

In addition to the investment appraisal techniques, there are various supplementary capital budgeting tools available in making and supporting investment decision. Ryan and Ryan (2002) illustrated the followings are major tools of risk analysis and those were described by them in the following manner.

Sensitivity analysis allows to assess changes provided that one variable input change at a time for example to assess the change in NPV if sales change. Scenario analysis is similar to sensitivity analysis however, more than one variable changes at a time for scenario analysis. Inflation adjusted cash flows adjusts expected future cash flows by an estimated inflation factor. Economic value added describes managerial effectiveness in a given year, often calculated in terms of net profit after tax that support operations of a firm .Internal IRR is the difference in cash flows of two comparison projects, commonly used in replacement decisions. Simulation is a method for calculating the probability distribution of the possible outcome. PERT/CPM is the analysis and mapping most efficient duration based financial decision. Decision tree is a decision making tool showing sequential outcomes, associated with their probabilities. Complex mathematical model deals with various option pricing model techniques, complex, real option, and firm specific proprietary models and methods. Linear programming is the mathematical solution that identifies a set of projects and works to maximize NPV subject to constraints. Option pricing model takes either binomial option pricing model or the Black-Scholes option pricing model. The Black-Scholes option pricing 
model used by firms like Merck with high research and development expenditures, although large positive NPV investments (Ryan \& Ryan, 2002). Real Options discuss the opportunity for expansion, contraction or abandonment of a capital project before the project life span (Ryan \& Ryan, 2002)

Mostly, the long run success of a firm depends on excellent investment decisions than on any other factors (Megginson, Smart \& Lucey,2008). Majority of firms' investment decision involves acquisition of fixed assets, for example, purchase of land, plant, equipment, and building. Effective investment decision is thus essential to help mould the firm's future opportunities and to deserve competitive advantage.

'Capital investment decisions are critical in managing strategic change and sustaining long term corporate performance'Emmanuel, Harris \& Komakech, 2010, p. 47 ). Instituting a systematic capital budgeting decision process proffers procedures to mitigate consequences of subjective capital expenditure decision making. The investment decision making is not a simple or straight forward approach, the risk is an important element in making investment decision.

\subsection{Empirical review}

Several studies (Klammer, 1973;Kim, 1981; Pike, 1984; Farragher, Kleiman \& Sahu, 2001) have noted that analyzing the relationship between capital budgeting sophistication and firm's performance and the use of accounting information when constructing performance measures is widespread. Munyao (2010) suggested that sophisticated capital budgeting procedures can under the assumption of economic rationality be regarded as a means a firm uses in order to fulfill its objective of shareholders wealth maximization.

In Jordan, Ramadan (1991) found an increasing trend toward adopting more sophisticated capital budgeting techniques by Jordanian Industrial Corporations when evaluating capital investment projects. Ramadan neither found a relationship between the techniques used and the performance of the firms, nor between the firm size and the techniques used. The sample of Ramadan's study (1991) includes all listed Jordanian industrial corporations; 46 corporations. A questionnaire was addressed to the persons in charge of the capital budgeting decision, 37 usable replies have been analyzed to reach at the results of the study.Some corporations in Ramadan's study (1991) refused to fill the questionnaire because they either claimed privacy issues, not having time, or tired of filling frequently flowing questionnaires. The questionnaire that Ramadan (1991) used, explored the techniques used by the respondents and some explanations for that use. NPV and PI were the most popular 20 techniques followed by the PBP, 30\% of the firms use more than one technique. The managers use the DCF techniques because of their beliefs about the superiority of these techniques knowing that most of the managers are well educated and experienced. Moreover, firms are more adapting to the changes in the investment environment. The PBP is still used as a supplementary technique since it gives a good measure for the maturity of the project and because it is a good tool when the liquidity is the concern. When analyzing the relationship between the performance and the technique used, Ramadan (1991) found that on the long run there was no relationship between these variables, and to make his result more reliable he 
included the firms that use either the DCF techniques, or the Non-DCF ones, but not both. Ramadan (1991) used simple measures for the performance like Return on Investment. The analysis revealed that all variables included in the model except the degree of sophistication have their expected effects on the performance. The researchers expected that better performing companies use sophisticated capital budgeting practices, the results showed a negative relationship between performance and degree of capital budgeting sophistication. The results of Farragher et al.'s study (2001) are consistent with the results of Ramadan's study (1991).

Farragher et al (2001) studied the relationship between the use of sophisticated capital budgeting practices and corporate performance. The researchers developed a multiple regression model that explains the performance through some variables including the degree of capital budgeting sophistication. The data measuring the company's degree of sophistication was gathered through a mailed questionnaire addressed to CFOs of 379 American industrial large companies, 34\% returned questionnaire were usable replies.

In the Kingdom of Saudi Arabia, El-ebaishe, Karbhari, and Naser (2003) examined the use of selected management accounting techniques by medium and large sized Saudi manufacturing firms. A questionnaire was developed in line with previous researches, the questionnaire included 15 different management accounting techniques; capital budgeting is one of them. Before distributing the questionnaire, it was pretested through pilot interviews with 7 CFOs of the manufacturing companies. These pilot interviews helped in minimizing the wording ambiguity of the questionnaire and improving the relevance of its questions. The pilot interviews made the researchers exclude the small firms from their study after being uncertain about their responses. The results showed that vast majority of the surveyed companies use management accounting techniques employed by the study. Regarding Capital budgeting, $60 \%$ of the sample use capital budgeting when making capital investment decisions.

Brounen, Jong and Koedijk (2004) studied corporate finance in Europe. They examined the gap between theory and practice by measuring the extent to which theoretical concept are adopted by professionals. The researchers used a questionnaire developed by Graham, \& Harvey (2002), which was awarded a Jensen Price in 2001. A sample of 313 European 21 CFOs answered the questions and the results showed that PBP technique is still used remarkably in Europe. The capital assets pricing model is the most used one to estimate the cost of equity. There is a positive relationship between the size of the firm on one hand and the use of DCF techniques and the capital assets pricing model on the other hand. Small firms and firms that are less oriented toward maximizing the shareholders wealth are more likely to apply PBP. These firms use whatever their investors tell them to use as cost of capital when applying DCF techniques. The education background of the respondents was irrelevant to the trend of using specific capital assets pricing model. The gap between theory and practice appears to be consistent across borders. The results of Brounen et al.'s study concerning capital budgeting was not significantly different from the results of the study conducted on the U.S firms by Graham and Harvey (2002). 
The relationship between the capital expenditures and the corporate earning was the title of a study conducted on Tai corporations by Jiang, Chen \& Huang (2006). The study examined 357 manufacturing corporations listed on the Taiwan stock exchange. A sample period of 11 years was divided into capital investment period and performance period. The sample firms are grouped into eight portfolios ranked by capital investment ratio which is estimated from the investment period. The researchers examined the earnings in the performance period for the eight portfolios to see if any positive relationship exists. The results of Jiang et al.'s study (2006) showed a significant positive relationship between the performance of corporations in the sample and the capital expenditures. The study did not include the effect of the techniques used when making the capital expenditures, but it implicitly assumed the use of NPV technique.

Graham and Harvey (2002) reported that chief financial officers (CFO) said that they always or almost used a particular evaluation technique i.e., IRR and NPV. The survey was based on the responses of three hundred and ninety two CFOs. Another study conducted by Ehrhardt and Wachowicz (2006) found that according to their surveys, most companies use DCF methods to evaluate capital budgeting decisions. DCF methods typically assume that a project's initial cash outlay (ICO) is known with certainty.

A proper capital budgeting analysis should incorporate the additional risk that due to uncertain ICO. Sensitivity analysis is an effective way to address ICO risk, but the finance literature often overlooks the adjustments needed to satisfactory address ICO risk within a sensitivity analysis (as cited in Rishi \& Rao,2005)

Verbeteen (2006) classified the capital budgeting practices as simple or naive capital budgeting practices (such as the payback and accounting rate of return) generally do not use cash flows, do not consider the time value of money and do not incorporate risk in a systematic manner. Advanced capital budgeting practices (such as the internal rate of return and the net present value) are those that consider cash flows, risk, and the time value of money. Capital budgeting decision makers have used various techniques to evaluate the proposed capital investment projects, and to determine the ones that benefit the firm the most. The adoption of particular techniques rather than others is determined by individual

A study conducted on Jordanian corporations provided empirical evidence on capital budgeting practices in Jordan, the study was conducted by Khamees, Al-Fayoumi, and Al-Thuneibat. (2010). The researchers used a questionnaire and conducted interviews to collect the data of the study. Most of the 28 questions in the questionnaire were closed type questions, while the interviews were conducted before the distribution of the questionnaire. The interviews were conducted to clarify any ambiguity related to the questions in the questionnaire, to assure confidentiality to the respondents, and to show respondents the importance of their responses. According to the previous studies, investment appraisal techniques and risk analysis techniques have been included under capital investment appraisal practices. Based on literature review following hypotheses have been formulated to conduct the study. 
$\mathrm{H}_{1}$ : There is significant relationship between use of investment appraisal techniques and effectiveness of investment decisions

$\mathrm{H}_{2}$ : There is significant relationship between use risk analysis techniques and effectiveness of investment decisions

Further, following conceptual framework was formulated to examine the relationship between capital investment appraisal practices and effectiveness of investment decisions with support of literature review and empirical review.


Figure 1. Conceptual framework

\section{Methodology}

The study focused to examine the relationship between use of investment appraisal practices and effectiveness of investment decision making in listed Manufacturing companies in Sri Lanka. Deductive approach was chosen for this study because it best suited as it was exploratory and gave the researcher an opportunity collect the relevant data to meet the objectives of the study. There are 295 companies listed on Colombo stock exchange representing 20 business sectors. From the 20 business sectors, the manufacturing sector was selected for this study as it gives the much contribution to the GPD than other sectors. Population consisted of the 40 manufacturing companies listed on the Colombo Stock Exchange. 20 manufacturing companies were randomly selected as a sample from the population of 40 listed manufacturing companies. The field survey was used to collect the data from January to March and questionnaire was used as a survey instrument.

\subsection{Data collection}

20 listed manufacturing companies in Sri Lanka have been randomly selected and self-reported questionnaire has been administered to gather data. The questionnaire adopted has been originally used and developed in pervious seminal studies (Verma et al., 2009; Graham \& Harvey, 2001). There are some modifications have been done on questionnaire based on the Sri Lankan context. The structured questionnaire includes closed ended questions inquiring the 


\section{Macrothink}

size of capital budgeting, educational qualification and experience of the people who responded to the survey and investment appraisal techniques and risk analysis techniques were on the Likert scale of 1 to 5 . Effectiveness of investment decision was measured by perceived performance of Chief Financial Officers (CFOs) on the investment decision. Questions on effectiveness of investment decision were developed based on the previous studies of Verbeeten (2006) and Pike (1988) then questionnaire was modified based on the Sri Lankan context and used Likert scale of 1 to 5. Firm size was considered as control variable as suggested from previous studies that if the firm size is high, company can employ the staff to evaluate the investment projects and make effective investment decision (Verbeeten,2006). Total assets of the companies were considered as size of the firms and which were collected from annual reports of the respective companies. One of the researchers visited to 20 listed manufacturing companies by getting appointment and collected the data by issuing questionnaire to the CFOs / Finance managers/ management accountants/ budget controllers of the companies. A reliability analysis of the item-scales was performed using SPSS. Cronbach's alpha $(\alpha)$ values were assessed for each variable with item-scales. The reliability of the measures was well above the minimum threshold of 0.60 in every case (Gliner and Morgan, 2000). Thus, it can be concluded that all of the measures were generally reliable.

\section{Data Analysis}

\subsection{Descriptive Statistics on demographic characteristics}

Table 1 shows the demographical characteristics of the respondents; it shows the age of the company, planning horizon of the capital budget, size of capital budgeting, educational qualification and the experience of the CFO who responded to the questions of the questionnaire. The table shows the frequency, the percentage and mean of each variable as follows. 


\section{Ml Macrothink}

Table 1. Demographical characteristics

\begin{tabular}{|c|c|c|c|c|}
\hline Panels & & & Frequency & Percent \\
\hline \multirow{5}{*}{ Panel A } & \multirow{5}{*}{ Age } & below 30 & 5 & 25.0 \\
\hline & & $30-40$ & 7 & 35.0 \\
\hline & & $40-50$ & 3 & 15.0 \\
\hline & & more than 50 & 5 & 25.0 \\
\hline & & Total & 20 & 100.0 \\
\hline \multirow{6}{*}{ Panel B } & \multirow{6}{*}{$\begin{array}{c}\text { Capital } \\
\text { budgeting } \\
\text { planning } \\
\text { horizon }\end{array}$} & 1 year ahead & 9 & 45.0 \\
\hline & & 2 years ahead & 4 & 20.0 \\
\hline & & 3 years ahead & 2 & 10.0 \\
\hline & & 4 years ahead & 3 & 15.0 \\
\hline & & More than 4 years & 2 & 10.0 \\
\hline & & Total & 20 & 100.0 \\
\hline \multirow{6}{*}{ Panel C } & \multirow{6}{*}{$\begin{array}{c}\text { Size of capital } \\
\text { budget }\end{array}$} & $<10$ million & 4 & 20.0 \\
\hline & & 10-99 million & 5 & 25.0 \\
\hline & & 100-499 million & 5 & 25.0 \\
\hline & & 500-999 million & 3 & 15.0 \\
\hline & & $>1$ billion & 3 & 15.0 \\
\hline & & Total & 20 & 100.0 \\
\hline \multirow{4}{*}{ Panel D } & \multirow{4}{*}{$\begin{array}{l}\text { Respondents } \\
\text { Experience }\end{array}$} & less than 5 years & 9 & 45.0 \\
\hline & & 5 to 10 years & 5 & 25.0 \\
\hline & & more than 10 years & 6 & 30.0 \\
\hline & & Total & 20 & 100.0 \\
\hline \multirow{4}{*}{ Panel E } & \multirow{4}{*}{$\begin{array}{l}\text { Education } \\
\text { qualification of } \\
\text { respondents }\end{array}$} & Bachelor degree & 5 & 25.0 \\
\hline & & MBA & 6 & 30.0 \\
\hline & & Professional & 9 & 45.0 \\
\hline & & Total & 20 & 100.0 \\
\hline
\end{tabular}

Source: Survey data

\section{Panel A: Age}

The sampled manufacturing companies have been classified in terms of number of years which are in business. Number of years has been categorized into four groups which are presented in Panel A. 35 percent of the sample companies have been in business between 30 and 40 years (n-7). Five companies (25 percent) have less than 30 years in business. Five companies (25 percent) have more than 50 years in business. Remaining companies reported that they are operating business between 40 and 50 years.

\section{Panel B: Capital budgeting planning horizon}

The sampled manufacturing companies have been classified in terms of capital budgeting planning horizon. Number of years has been categorized into five groups which are presented in Panel B. 45 percent of the sample companies involved with the capital budgeting 1 year ahead (n-9). Four companies (20 percent) involved with 2 years ahead. Three companies (15 
percent) involved with 4 years ahead. Remaining companies reported that same percentage they involved Capital budgeting planning horizon.

\section{Panel C: Size of capital budgeting}

Size of the capital budget has been categorized into five groups which are presented in Panel C. The size generally takes minimum of ten million and a maximum of more than one billion. 20 percent of companies' size of the capital budget is less than ten million while only 15 percent represented for more than one billion; 25 percent of companies' capital budget is between 10 and 99 million. Five companies ( 25 percent) mentioned that their size of the capital budget is 100-499 million and rest of the companies (15 percent) falls between 500 and 999 million.

\section{Panel D: Respondents experience}

Experience of respondents has been classified into three groups in terms of number of years they worked in a particular profession. 45 percent of respondents are having less than 5 years of experience. 30 percent of respondents reported that they have experience more than 10 years. Remaining respondents' experience observed between 5 to 10 years. Results are depicted in table 1 Panel D.

\section{Panel E: Education qualification of respondents}

Classification of educational qualification of respondents is presented in Table I Panel E. 45 percent $(n=9)$ of respondents had professional qualification, followed by MBA and bachelor degree qualification with 30 percent $(n=6)$ and 25 percent $(n=5)$ respectively.

4.2 Analysis on the use of capital investment appraisal practices 
Table 2. Investment appraisal techniques for evaluating investment projects in Sri Lanka

\begin{tabular}{|c|c|c|c|c|c|c|c|c|}
\hline & $\begin{array}{l}\text { Never } \\
\text { (1) }\end{array}$ & $\begin{array}{l}\text { Rarely } \\
\text { (2) }\end{array}$ & $\begin{array}{c}\text { Some } \\
\text { times } \\
\text { (3) }\end{array}$ & $\begin{array}{l}\text { Often } \\
\text { (4) }\end{array}$ & $\begin{array}{c}\text { Always } \\
\text { (5) }\end{array}$ & Total & Mean & Rank \\
\hline & $\%$ & $\%$ & $\%$ & $\%$ & $\%$ & $\%$ & & \\
\hline Payback (PB) & $25(5)$ & $10(2)$ & $10(2)$ & $10(2)$ & $45(9)$ & $100(20)$ & 3.4 & 4 \\
\hline $\begin{array}{l}\text { Discounted Payback } \\
\text { (DPB) }\end{array}$ & $10(2)$ & $0(0)$ & $5(1)$ & $45(9)$ & $40(8)$ & $100(20)$ & 4.05 & 3 \\
\hline $\begin{array}{l}\text { Accounting Rate of } \\
\text { Return (ARR) }\end{array}$ & $35(7)$ & $10(2)$ & $10(2)$ & $30(6)$ & $15(3)$ & $100(20)$ & 2.8 & 6 \\
\hline Net Present Value(NPV) & $0(0)$ & $0(0)$ & $0(0)$ & $20(4)$ & $80(16)$ & $100(20)$ & 4.65 & 1 \\
\hline $\begin{array}{l}\text { Internal Rate of Return } \\
\text { (IRR) }\end{array}$ & $0(0)$ & $0(0)$ & $25(5)$ & $15(3)$ & $60(12)$ & $100(20)$ & 4.35 & 2 \\
\hline $\begin{array}{l}\text { Modified Internal Rate } \\
\text { of Return (MIRR) }\end{array}$ & $45(9)$ & $20(4)$ & $10(2)$ & $10(2)$ & $15(3)$ & $100(20)$ & 2.30 & 7 \\
\hline $\begin{array}{l}\text { Adjusted Present Value } \\
\text { (APV) }\end{array}$ & $50(10)$ & $10(2)$ & $10(2)$ & $25(5)$ & $5(1)$ & $100(20)$ & 2.25 & 8 \\
\hline Profitability Index (PI) & $30(6)$ & $15(3)$ & $10(2)$ & $15(3)$ & $30(6)$ & $100(20)$ & 2.9 & 5 \\
\hline Real option theory & $70(14)$ & $20(4)$ & $5(1)$ & $0(0)$ & $5(1)$ & $100(20)$ & 1.50 & 10 \\
\hline Game theory & $90(18)$ & $5(1)$ & $0(0)$ & $0(0)$ & $5(1)$ & $100(20)$ & 1.25 & 11 \\
\hline Non-financial decision & $55(11)$ & $10(2)$ & $15(3)$ & $5(1)$ & $15(3)$ & $100(20)$ & 2.15 & 9 \\
\hline
\end{tabular}

Source: Survey data

CFOs further have been requested to report use of capital budgeting methods and how they frequently used these methods on a Likert scale from always (5) to never (1). Results of the prevalence usage of capital budgeting methods have been summarized in Table 2. NPV is the most preferred method of investment appraisal where 80 percent of CFOs are "always" preferred it which yielding mean value of 4.65.

This is followed by IRR "always" by 60 percent $(\mathrm{M}=4.35)$. DPB is the next "always" preferred method by 45 percent $(\mathrm{M}=3.4) .45$ percent CFOs revealed that DPB is an "often" preferred method which is dominant among all methods followed by PB (10 percent), IRR and NPV (15 percent and 20 percent). This findings are consistent with the studies of Babu and Sharma (1995),Cooper et al.(2002), Verma et al.(2009), Truong, Partington, and Peat(2008) and Nurullah and Kengatharan (2015). The rest of the methods like PI, ARR, MIRR, and APV, Real option theory, Game theory and Non-financial decision are not well popular in its usage where mean values are less than 3.0. Appraisal techniques have been considered which have 
mean value more than three for the analysis on the relationship between investment appraisal techniques and effectiveness of investment decision, as they are mostly used by selected companies.

Table 3. Risk analysis techniques used by Sri Lankan listed manufacturing companies

\begin{tabular}{|c|c|c|c|c|c|c|c|c|}
\hline & Never & Rarely & Sometimes & Often & Always & Total & Mean & Rank \\
\hline & $\%$ & $\%$ & $\%$ & $\%$ & $\%$ & $\%$ & & \\
\hline Sensitivity analysis & $10(2)$ & $0(0)$ & $20(4)$ & $40(8)$ & $30(6)$ & $100(20)$ & 3.80 & 4 \\
\hline Scenario Analysis & $20(4)$ & $5(1)$ & $20(4)$ & $20(4)$ & $35(7)$ & $100(20)$ & 3.45 & 5 \\
\hline Monte Carlo simulation & $60(12)$ & $15(3)$ & $25(5)$ & $0(0)$ & $0(0)$ & $100(20)$ & 1.65 & 13 \\
\hline Decision tree & $30(6)$ & $10(2)$ & $20(4)$ & $30(6)$ & $10(2)$ & $100(20)$ & 2.80 & 6 \\
\hline CAPM & $45(9)$ & $25(5)$ & $20(4)$ & $10(2)$ & $0(0)$ & $100(20)$ & 1.95 & 11 \\
\hline High cutoff rate & $70(14)$ & $10(2)$ & $10(2)$ & $10(2)$ & $0(0)$ & $100(20)$ & 1.60 & 14 \\
\hline Uncertainty absorption & $50(10)$ & $0(0)$ & $25(5)$ & $25(5)$ & $0(0)$ & $100(20)$ & 2.25 & 9 \\
\hline Breakeven Analysis & $0(0)$ & $0(0)$ & $10(2)$ & $20(4)$ & $70(14)$ & $100(20)$ & 4.60 & 1 \\
\hline Adjusting the required return & $35(7)$ & $15(3)$ & $20(4)$ & $25(5)$ & $5(1)$ & $100(20)$ & 2.50 & 7 \\
\hline Inflation adjusted cash flow & $15(3)$ & $0(0)$ & $10(2)$ & $25(5)$ & $50(10)$ & $100(20)$ & 3.95 & 2 \\
\hline Market value Added & $40(8)$ & $10(2)$ & $25(5)$ & $15(3)$ & $10(2)$ & $100(20)$ & 2.45 & 8 \\
\hline $\begin{array}{l}\text { Complex Mathematical } \\
\text { Model }\end{array}$ & $65(13)$ & $30(6)$ & $5(1)$ & $0(0)$ & $0(0)$ & $100(20)$ & 1.40 & 16 \\
\hline Linear programming & $60(12)$ & $35(7)$ & $5(1)$ & $0(0)$ & $0(0)$ & $100(20)$ & 1.45 & 15 \\
\hline Short payback period & $55(11)$ & $15(3)$ & $10(2)$ & $15(3)$ & $5(1)$ & $100(20)$ & 2.00 & 10 \\
\hline Use of certainty equivalent & $65(13)$ & $10(2)$ & $15(3)$ & $10(2)$ & $0(0)$ & $100(20)$ & 1.70 & 12 \\
\hline Probability Analysis & $10(2)$ & $10(2)$ & $10(2)$ & $25(5)$ & $45(9)$ & $100(20)$ & 3.85 & 3 \\
\hline
\end{tabular}

Source: Survey data

Risk is mostly intertwined with capital investment decision. Table 3 summarizes the risk analysis techniques used for incorporating risk in the investment analysis. According to the table 3, majority of CFOs revealed that they use Breakeven Analysis for incorporating risk in the evaluation of investment proposal (always 70 percent and often 20 percent) yielding mean value of 4.60. Inflation adjusted cash flow is the second most preferred method for incorporating risk (always 50 percent and often 25 percent) yielding second highest mean value of 3.95, followed by Probability Analysis (always 45 percent and often 25 percent), Sensitivity analysis (always 30 percent and often 40 percent) and Scenario Analysis (always 35 percent and often 20 percent) yielding next highest mean value of 3.85, 3.80 and 3.45, respectively. All other risk analysis tools are hardly used in sampled companies. The results are consistent with the studies of Babu and Sharma (1995) Verma et al. (2009) and Nurullah and Kengatharan (2015). Risk analysis techniques have been considered which have mean value more than three 


\section{Macrothink Institute ${ }^{\mathrm{TM}}$}

for the analysis on the relationship between risk analysis techniques and effectiveness of investment decision, as they are mostly used by selected companies.

\subsection{Correlation analysis}

Correlation analysis is the statistical tool that can be utilized to determine the level of association between two variables (Levin and Rubin, 1998). This analysis can be seen as the initial step in statistical modeling to determine the relationship between the investment appraisal practices and effectiveness of investment decision. Result of correlations analysis presented in the table 4 .

Table 4. Correlations between investment appraisal techniques and effectiveness of investment decision

\begin{tabular}{|c|c|c|c|c|c|c|}
\hline \multicolumn{7}{|c|}{ Correlations } \\
\hline & & PB & DPB & NPV & IRR & Effectiveness \\
\hline \multirow{2}{*}{ PB } & Pearson Correlation & 1 & & & & \\
\hline & Sig. (2-tailed) & & & & & \\
\hline \multirow{2}{*}{ DPB } & Pearson Correlation & $.552^{*}$ & 1 & & & \\
\hline & Sig. (2-tailed) & .012 & & & & \\
\hline \multirow{2}{*}{ NPV } & Pearson Correlation & .193 & .022 & 1 & & \\
\hline & Sig. (2-tailed) & .415 & .928 & & & \\
\hline \multirow{2}{*}{ IRR } & Pearson Correlation & -.132 & -.068 & $.498^{*}$ & 1 & \\
\hline & Sig. (2-tailed) & .579 & .775 & .025 & & \\
\hline \multirow{2}{*}{ Effectiveness } & Pearson Correlation & -.389 & $-.556^{*}$ & $.535^{*}$ & $.607^{* *}$ & 1 \\
\hline & Sig. (2-tailed) & .090 & .011 & .015 & .005 & \\
\hline \multicolumn{7}{|c|}{$\begin{array}{l}* \text {. Correlation is significant at the } 0.05 \text { level (2-tailed). } \\
* * \text {. Correlation is significant at the } 0.01 \text { level (2-tailed). }\end{array}$} \\
\hline
\end{tabular}

Source: Survey data

As a result presented in table 4, DPB, NPV and IRR significantly associated with the effectiveness of investment decision. There was a positive relationship between NPV and effectiveness of investment decision that shows $\mathrm{r}=0.535$ at the significant level of $0.05(\mathrm{p}=$ 0.015 ) and also there was a positive relationship between IRR and effectiveness of investment decision that shows $r=0.607$ at the significant level of $0.01(p=0.005)$. Here the researcher found a negative relationship between the discounted payback period and effectiveness of investment decision that shows $\mathrm{r}=-0.556$ at the significant level of 0.05 . Any other $5 \%$ level of significant relationship among the variables was not found in this study. 


\section{Ml Macrothink}

Asian Journal of Finance \& Accounting ISSN 1946-052X 2017, Vol. 9, No. 2

Table 5. Correlations between risk analysis techniques and effectiveness of investment decisions

\begin{tabular}{|c|c|c|c|c|c|c|c|}
\hline \multicolumn{8}{|c|}{ Correlations } \\
\hline & & $\begin{array}{c}\text { Sensitivity } \\
\text { analysis }\end{array}$ & $\begin{array}{l}\text { Scenario } \\
\text { analysis }\end{array}$ & \begin{tabular}{|c|} 
Breakeven \\
analysis
\end{tabular} & $\begin{array}{l}\text { Inflation } \\
\text { adjusted } \\
\text { cash flow }\end{array}$ & $\begin{array}{l}\text { Probability } \\
\text { analysis }\end{array}$ & Effectiveness \\
\hline \multirow{2}{*}{$\begin{array}{l}\text { Sensitivity } \\
\text { analysis }\end{array}$} & $\begin{array}{l}\text { Pearson } \\
\text { Correlation }\end{array}$ & 1 & & & & & \\
\hline & Sig. (2-tailed) & & & & & & \\
\hline \multirow[t]{2}{*}{ Scenario analysis } & $\begin{array}{l}\text { Pearson } \\
\text { Correlation }\end{array}$ & $.566^{* *}$ & 1 & & & & \\
\hline & Sig. (2-tailed) & .009 & & & & & \\
\hline \multirow{2}{*}{$\begin{array}{l}\text { Breakeven } \\
\text { analysis }\end{array}$} & $\begin{array}{l}\text { Pearson } \\
\text { Correlation }\end{array}$ & .026 & -.272 & 1 & & & \\
\hline & Sig. (2-tailed) & .914 & .247 & & & & \\
\hline \multirow{2}{*}{$\begin{array}{l}\text { Inflation adjusted } \\
\text { cash flow }\end{array}$} & $\begin{array}{l}\text { Pearson } \\
\text { Correlation }\end{array}$ & $.670^{* *}$ & .298 & .356 & 1 & & \\
\hline & Sig. (2-tailed) & .001 & .203 & .123 & & & \\
\hline \multirow{2}{*}{$\begin{array}{l}\text { Probability } \\
\text { analysis }\end{array}$} & $\begin{array}{l}\text { Pearson } \\
\text { Correlation }\end{array}$ & -.273 & -.065 & $.546^{*}$ & .102 & 1 & \\
\hline & Sig. (2-tailed) & .245 & .784 & .013 & .669 & & \\
\hline \multirow[t]{2}{*}{ Effectiveness } & $\begin{array}{l}\text { Pearson } \\
\text { Correlation }\end{array}$ & $-.486^{*}$ & -.179 & .138 & -.226 & .339 & 1 \\
\hline & Sig. (2-tailed) & .030 & .451 & .563 & .337 & .144 & \\
\hline
\end{tabular}

Source: Survey data

As a result of correlations analysis presented in table 5, there was a negative relationship between the sensitivity analysis and effectiveness of investment decision $(r=-0.486, p<0.05)$. None of the other techniques were significantly associated with effectiveness of investment decision in this study.

\subsection{Regression analysis}

Regression analysis was performed to evaluate the impact of capital investment appraisal techniques and effectiveness of investment decision. Result of regression analysis presented in the table 6. As per the result, specification of five variables firm size, PB, NPV, IRR, DPB revealed the ability to predict the effectiveness of investment decision (Adj. $\mathrm{R}^{2}=75.3 \%$ ) in this 
model. It denoted that $75.3 \%$ of the observed variability in effectiveness could be explained by the differences in independent variable such as PB, NPV, IRR, DPB and firm size. The remaining $24.7 \%$ of the variances was not explained in this model.

From the table 6 , for model $1-\mathrm{F}$ value is $8.554(\mathrm{P}=0.001,<0.01)$. It was noted that the corresponding $\mathrm{F}$ Value was significant. Thus the distribution of effectiveness explained a significant portion of the variation in investment appraisal techniques evidenced by the significant $\mathrm{p}$-value. Therefore model was significant.

Model 1: Effectiveness $=1.385_{\beta 0^{-}} 0.046 \mathrm{~PB}^{-} 0.150_{\mathrm{DPB}}+0.413_{\mathrm{NPV}}+0.184_{\mathrm{IRR}}+0.050_{\mathrm{FS}}(1)$

Table 6. Regression analysis

\begin{tabular}{|c|c|c|c|c|c|}
\hline \multirow{2}{*}{\multicolumn{2}{|c|}{ Model }} & \multicolumn{2}{|c|}{ Unstandardized Coefficients } & \multirow[t]{2}{*}{$\mathrm{T}$} & \multirow[t]{2}{*}{ Sig. } \\
\hline & & $\mathrm{B}$ & Std. Error & & \\
\hline \multirow{6}{*}{1} & (Constant) & 1.385 & 1.020 & 1.357 & .196 \\
\hline & PB & -.046 & .042 & -1.098 & .291 \\
\hline & DPB & -.150 & .059 & -2.539 & .024 \\
\hline & NPV & .413 & .168 & 2.454 & .028 \\
\hline & IRR & .184 & .079 & 2.316 & .036 \\
\hline & $\begin{array}{l}\text { Firm size } \\
(\mathrm{FS})\end{array}$ & .050 & .071 & .706 & .491 \\
\hline \multicolumn{6}{|c|}{ Adj. $\mathrm{R}^{2}=0.753 \mathrm{~F}=8.554 \mathrm{P}=0.001$} \\
\hline
\end{tabular}

a. Dependent Variable: Effectiveness

In terms of $\mathrm{PB}$, the coefficient of $\mathrm{PB}$ ( $\operatorname{coef}=-0.046, \mathrm{P}=.291$ ) was negative but not significant. Therefore it was concluded that there was no significant relationship between $\mathrm{PB}$ and effectiveness of investment decision. In addition, the coefficient of DPB was negatively significantly influenced on effectiveness of investment decision $($ coef $=-.150, \mathrm{P}<0.05)$. Reason for the negative relationship between DPB and effectiveness of investment decision may be DPB is not considered the risk analysis in a systematic way and was not considered time value of money. NPV (coef $=.413, \mathrm{P}<0.05$ ) and IRR (coef $=.184, \mathrm{P}<0.05$ ) are significantly positively influenced on effectiveness of investment decision. Therefore, hypothesis $H_{1}$ is supported that there is significant relationship between investment appraisal techniques and effectiveness of investment decision in terms of NPV, IRR and DPB. NPV and IRR are treated as advanced investment appraisal techniques in the literature (Verbeeten,2006). Advanced investment appraisal techniques lead to higher level of performance (Farragher, Kleiman \& Sahu, 2001). Therefore the findings of the study are consistent with the literature.

Model 2: Effectiveness $=4.013_{\beta 0}-0.220_{\mathrm{Sen}}+0.052_{\mathrm{Sce}}+0.070_{\mathrm{Be}}+0.023_{\mathrm{In}}+0.035_{\mathrm{Pa}}-0.004 \mathrm{~F}$. 
Table 7. Regression analysis for risk analysis techniques

\begin{tabular}{|c|c|c|c|c|c|}
\hline \multicolumn{6}{|c|}{ coefficients $^{\mathrm{a}}$} \\
\hline \multicolumn{2}{|c|}{ Model } & \multicolumn{2}{|c|}{ unstandardized coefficients } & \multirow[t]{2}{*}{$\mathrm{t}$} & \multirow[t]{2}{*}{ sig. } \\
\hline & & $\mathrm{b}$ & std. error & & \\
\hline \multirow{7}{*}{2} & (constant) & 4.013 & 1.633 & 2.458 & .029 \\
\hline & Sensitivity analysis (Sen) & -.220 & .152 & -1.449 & .171 \\
\hline & Scenario analysis (Sce) & .052 & .092 & .565 & .582 \\
\hline & Breakeven analysis $(\mathrm{Be})$ & .070 & .219 & .322 & .752 \\
\hline & $\begin{array}{l}\text { Inflation adjusted cash } \\
\text { flow (In) }\end{array}$ & .023 & .107 & .217 & .832 \\
\hline & Probability analysis $(\mathrm{Pa})$ & .035 & .103 & .340 & .739 \\
\hline & Firm size (Fs) & -.004 & .130 & -.029 & .977 \\
\hline
\end{tabular}

.Source : Survey data

As per the results presented in the table 7 , model was not significant in this study $(\mathrm{F}=0.941, \mathrm{P}>$ 0.05). It was not found any significant relationship between risk analysis techniques and effectiveness investment decision. Therefore $\mathrm{H}_{2}$ was not supported that there is no significant relationship between use risk analysis techniques and effectiveness of investment decision. Findings of the study is inconsistent with the literature (e.g: Pike,1988)

\section{Conclusion}

Primary objective of the present study was to examine the relationship between use of capital investment appraisal practices and effectiveness of investment decision of listed manufacturing companies in Sri Lanka. Capital investment appraisal practices were measured by capital investment appraisal techniques and risk analysis techniques of the projects. Effectiveness of investment was measured by perceptions of CFOs on the performance on investment. Firm size was used as the control variable to examine the relationship between investment appraisal practices and effectiveness of investment decision. The study employed a field survey from January to March 2017 and primary data was collected through self-administered questionnaires from randomly selected 20 listed manufacturing companies. The data was analyzed using the descriptive analysis and inferential statistical analysis by using statistical package for social sciences (SPSS) version 20. Results of the study revealed that NPV and IRR significantly positively related to effectiveness of investment decision while DPB significantly negatively related to effectiveness of investment decision of listed manufacturing companies in Sri Lanka. Risk analysis techniques were not significantly related to effectiveness of investment decision. Findings of the study may useful to the investment decision makers in order to achieve the shareholders wealth. 


\section{References}

Arnold, G.C., \& Hatzopoulos, P.D. (2000). The theory-practice gap in capital budgeting: evidence from the United Kingdom. Journal of Business Finance and Accounting, 10(5), 603-626. https://doi.org/10.1111/1468-5957.00327.

Babu, C. P., \& Sharma, A. (1995).Capital budgeting practices in Indian industry-an empirical study. ASCI Journal of Management, 25(1), 34-43.

Bennouna, K., Meredith,G. G., \& Marchant, T. (2010). Improved capital budgeting decision making: evidence from Canada. Management Decision, 48(2), 225-247. https://doi.org/10.1108/00251741011022590.

Bhimani, A., Horngren, C. T., Datar, S. M., \& Rajan, M.V. (2012). Management and cost accounting, $5^{\text {th }}$ edn., Prentice Hall.

Brealey,R.A., \& Myers,S.C.(2003). Principles of corporate finance, $7^{\text {th }}$ edn, International Edition,McGraw-Hill.

Brounen, D., de Jong, A., \& Koedijk, K. (2004). Corporate finance in Europe: confronting theory with practice. Financial Management, 33(4), 71-101.

Dayananda, D., Irons, R., Harrison, S., Herbohn, J. \& Rowland, P. (2002). Capital budgeting: financial appraisal of investment projects, Edinburgh: Cambridge University Press.

Ekeha,G.E.(2011).Capital budgeting practices and economic development: A comparative study of companies in Western Europe and West Africa. Available at http:// www.amazon.com/Capital-Budgeting-Pratices-Economic Development/dp/3844382593

Elumilade,D.O., Asaolu,T.O., \& Ologunde, A.O. (2006). Capital budgeting and economic development in the third world: The case of Nigeria. International Research Journal of Finance and Economics, 2(2), 136-152.

Emmanuel,C., Harris,E., \& Komakech,S. (2010). Towards a better understanding of capital investment decisions. Journal of Accounting and organizational change, 6(4), 477-504.

Farragher, E.J., Kleiman, R.T., \& Sahu, A.P. (2001). The association between the use of sophisticated capital budgeting practices and corporate performance. The Engineering Economist, 46(4), 300-311. https://doi.org/10.1080/00137910108967579.

Freeman, M., \& Hobbes, G. (1991). Capital budgeting: theory versus practice. Australian Accountant, 61(8), 36-41.

Gitman, L.J. (1988). Principles of managerial finance. New York: Harper and Row International.

Graham, J., \& Harvey, C. (2001). The theory and practice of corporate finance: evidence from the field. Journal of Financial Economics, 60(2-3), 187-243. 
Haka, S. F., Gordon, L. A., \& Pinches, G. E. (1985). Sophisticated capital budgeting selection techniques and firm performance. In Readings in Accounting for Management Control (pp. 521-545). Springer US.

Hatch,M.J., \& Cunliffe,A.L. (2006). Organization theory: modern, symbolic, and postmodern perspectives, $2^{\text {nd }}$ edn. Oxford University Press,p.4.

Hermes, N., Smid, P., \& Yao, L. (2007). Capital budgeting practices: a comparative study of the Netherlands and China. International Business Review, 16(5), 630-654. https://doi.org/10.1016/j.ibusrev.2007.05.002.

Jiang, C.H., Chen, H.L., \& Huang, Y.S. (2006). Capital expenditures and corporate earnings: Evidence from the Taiwan Stock Exchange. Managerial Finance, 32(11), 853-861. https://doi.org/10.1080/10913211.2013.860853

Khamees, B. A., Al-Fayoumi, N., \& Al-Thuneibat, A. A. (2010). Capital budgeting practices in the Jordanian industrial corporations. International Journal of Commerce and Management, 20(1), 49-63. https://doi.org/10.1108/10569211011025952.

Kim, S.H. (1981). An Empirical study on the relationship between capital budgeting practices and earnings performance. The Engineering Economist, 27(3), 185-196.

Klammer,T.(1973). The association of capital budgeting techniques with firm performance. Accounting Review, 48(2), 353-364.

Mao,J.C.T.(1970). Survey of capital budgeting: theory and practice. Journal of finance, 25(2), 349-360. https://doi.org/10.1111/j.1540-6261.1970.tb00513.x.

Megginson,W., Smart,S.B., \& Lucey,B.M. (2008). Introduction to corporate finance., Patrick Bond

Nurullah, M., \& Kengatharan,L.(2015). Capital budgeting practices: evidence from Sri Lanka. Journal of Advances in Management Research, 12(1), 55-82. https://doi.org/10.1108/JAMR-01-2014-0004.

Mustapha, M.Z., \& Mooi, S.T.L. (2001). Firm performance and degree of sophistication of capital budgeting practice: Some Malaysian Evidence. Proceedings of the Asia Pacific Management Conference, pp. 279-290

Pike, R.H. (1984). Sophisticated capital budgeting systems and their association with corporate performance. Managerial and Decision Economics, 5(2), 91-97. https://doi.org/10.1002/mde.4090050207.

Pike,R.(1996). A longitudinal survey on capital budgeting practices. Journal of Business financing and Accounting, 23(1), 79-92. https://doi.org/10.1111/j.1468-5957.1996.tb00403.x. Pike,R.H.(1988). An empirical study of the adoption of sophisticated capital budgeting practices and decision making effectiveness. Accounting and Business Research, 18(72), 341-351. https://doi.org/10.1080/00014788.1988.9729381. 


\section{Macrothink}

Asian Journal of Finance \& Accounting ISSN 1946-052X

Quirin, G.D.(1967). The capital expenditure decision, New York: Richard D.Irwin Publication.

Ryan, P. A., \& Ryan, G. P. (2002). Capital budgeting practices of the fortune 1000: how have things changed?. Journal of business and Management, 8(4), 355-364.

Truong, G., Partington,G., \& Peat,M.(2008). Cost of capital estimation and capital budgeting practice in Australia. Australian Journal of Management, 33(1),95-121.

Verbeeten, F.H.M. (2006). Do organizations adopt sophisticated capital budgeting practices to deal with uncertainty in the investment decision? A research note. Management Accounting Research, 17(1), 106-120. https://doi.org/10.1016/j.mar.2005.07.002.

Verma,S., Gupta,S., \& Batra,R. (2009). A survey of capital budgeting practices in corporate India, The Journal of Business Perspective, 13(3), 1-17. https://doi.org/10.1177/097226290901300301. 